\title{
Construindo Pontes de Saberes entre a Filosofia e a Literatura: o Encontro Dramático de Antoine Roquetin com a Liberdade.
}

\author{
Building Bridges of Knowledge between Philosophy and \\ Literature: Antoine Roquetin's Dramatic Encounter with \\ Freedom.
}

\author{
Anderson Luis da Paixão Café \\ (Centro Universitário Internacional, Brasil)
}

\begin{abstract}
Resumo
Compreender a forma pela qual Jean Paul Sartre articulou seus principais conceitos teóricos para construir a narrativa do seu $\mathrm{A}$ Náusea, que marcou as suas primeiras posições frente ao existencialismo francês, levando-o, inclusive, ao panteão dos grandes escritores franceses. Para isso, adotou-se uma pesquisa qualitativa, aplicada, exploratória e descritiva, na qual se construiu pontes de saberes entre a Filosofia e a Literatura. Os resultados da pesquisa mostraram alguns recortes textuais extraídos do romance em questão, na qual se evidenciou a forma pela qual o pensador francês articulou os conceitos de contingência, responsabilidade, desamparo, angústia e má-fé para construir a narrativa literária que mar-cou o encontro dramático de Antoine Roquentin com a liberdade. A pesquisa concluiu que A Náusea pode ser entendida como uma espécie de espelho que permite aos leitores perceberem-se enquanto indivíduos cada vez menos determinados pelas circuns-tâncias históricas, econômicas, sociais, políticas e/ou culturais e cada vez mais livres para construírem as suas vidas com a maior autenticidade possível.
\end{abstract}

Palavras-chave: Desamparo. Angústia. Liberdade. Responsabilidade. Contingência.

\begin{abstract}
To understand the way in which Jean Paul Sartre articulated his main theoretical concepts to construct the narrative of Nausea, which marked his first positions in the face of French existentialism, taking him, even, to the pantheon of the great French. To achieve this, a qualitative, applied, exploratory and descriptive research was adopted, in which knowledge bridges were built between Philosophy and Literature. The results of the research showed some textual excerpts extracted from the novel in question, in which it was evidenced the way in which the French thinker articulated the concepts of contingency, responsibility, helplessness, anguish and bad faith to build the literary narrative that marked Antoine Roquentin's dramatic encounter with freedom. The research concluded that, Nausea can be understood as a kind of mirror that allows readers to perceive themselves as individuals less and less determined by historical, economic, social, political circumstances and / or cultural and increasingly free to build their lives with the greatest possible authenticity.
\end{abstract}

Keywords: Contingency. Freedom. Responsibility. Anguish. Helplessness. 


\section{Introdução}

Na história do pensamento filosófico ocidental, não é incomum que estudantes, professores, pesquisadores e demais interessados pelo campo da Filosofia se deparem com uma tradição de estudos que revela, de certa forma, o esforço de diferentes pensadores para compreenderem a essência das coisas e da vida como uma forma de entenderem melhor os seus processos existenciais.

Desde os pré-socráticos, percebeu-se uma movimentação dos homens na tentativa de encontrarem o elemento fundamental ou a arché (que, em grego, significa o elemento que daria origem a todas as coisas existentes no mundo), de tal forma a explicar a essência do cosmos. Assim, foram diversas as respostas oferecidas pelos présocráticos aos fundamentos de constituição do homem e do mundo. Tales de Mileto, por exemplo, considerava a água a origem de todas as coisas. Anaxímenes de Mileto afirmava que a arché ou o princípio da vida era o ar. Já Heráclito de Éfeso dizia que o princípio da vida estava no devir, ou seja, no movimento, o que o levou a ser considerado, dentro da História da Filosofia, como o pai da dialética (REALE, 1989; ARANHA, 2000; CHAUÍ, 2002).

Dessa forma, é possível verificar que cada um dos pré-socráticos possuía uma resposta específica para a constituição da vida. Apesar de diferentes, todos eles acreditavam na existência de um princípio, isto é, de uma essência ou de um fundamento definidor de nossas existências. Da arché, enquanto princípio constitutivo da vida, o pensamento filosófico marchou em direção à valorização da razão ou da capacidade de julgamento racional do homem sobre a condição humana, o qual deu início à filosofia enquanto amor, respeito, apreciação e admiração pela sabedoria e pelo conhecimento (REALE,

Ágora Filosófica, Recife, v. 21, n. 1, p. 42-72, jan./abr., 2021 • 43 
1989; ARANHA, 2000; CHAUÍ, 2002).

Entre os socráticos, não havia mais espaço para se entender a essência da vida baseada, unicamente, nas explicações mitológicas ou da physis pré-socrática. Nesse momento da história do pensamento filosófico, o homem entendia que a sua essência estava pautada na razão, na medida em que buscava explicar o mundo e tudo o que o cercava com base no pensamento lógico e racional. Não é por acaso que uma das expressões filosóficas que mais marcou o mundo ocidental, na antiguidade, proveio de um dos maiores pensadores da filosofia, Sócrates com a frase: "Só sei que nada sei" (REALE, 1989; ARANHA, 2000; CHAUÍ, 2002).

Ao passo que na Antiguidade a essência ou o princípio de funcionamento do universo se pautou na valorização da razão, na Idade Média, experimentou-se a ascensão da Igreja Católica que se mostrou a principal instituição religiosa da época e que deu as diretrizes do pensar por mais de mil anos, ocasião na qual a essência do homem esteve pautada não mais na valorização do intelecto, mas, sobretudo, em sua capacidade de cultivar a fé ou a crença nas verdades sobrenaturais e divinatórias (REALE, 1989; ARANHA, 2000; CHAUÍ, 2002).

Passados mais de mil anos de dominação da concepção religiosa, a humanidade escreveu mais um capítulo de sua História ao resgatar os valores do pensamento antigo pautados na valorização da razão. Nesse contexto, assistiu-se ao Renascimento e à Revolução Científica e Cultural, apenas para citar alguns exemplos, que foram movimentos históricos e políticos, cuja pretensão foi recolocar o homem no centro do universo (REALE, 1989; ARANHA, 2000; CHAUÍ, 2002).

É nesse contexto histórico, chamado Idade 
Moderna, que se experimentou o resgate das luzes, isto é, da razão humana que repõe o homem no centro de todas as coisas. Se, na antiguidade, a máxima de Sócrates sintetizava muito bem o que seria a essência do homem, na modernidade, existe outra sentença que revela a compreensão de homem dessa época e que foi proferida por um dos maiores filosófico racionais de todos os tempos, Renê Descartes, cujo pensamento pode ser sintetizado na seguinte expressão: "Penso, logo existo" (REALE, 1989; ARANHA, 2000; CHAUÍ, 2002).

Entretanto, a valorização da razão, na modernidade, se diferencia muito da crença da razão na antiguidade, uma vez que enquanto os antigos a utilizava como uma maneira para pensar sobre as suas condições ontológicas diante dos mistérios da vida, na modernidade, pelo contrário, a utilização da razão estava associada à instrumentalização de saberes e à busca permanente de certezas. Dessa forma, a razão, na modernidade, passou a ser utilizada como instrumento de solução imediata de conflitos e problemas, a qual estava compromissada com a busca constante de felicidade.

É na modernidade, por assim dizer, que se encontram as maiores contradições nos discursos de valorização da razão humana. É nesse momento histórico, por exemplo, que o desenvolvimento da ciência ocorre sob a alegação de que se melhorariam as condições de vida da humanidade, mas foi justamente nesse momento histórico que as pessoas se depararam com duas grandes guerras mundiais que ceifaram milhares de vidas, provando que, de certa forma, a razão, por si só, não constituía a essência do homem como até então se havia pensado.

Foi nesse cenário de questionamento da valorização

Ágora Filosófica, Recife, v. 21, n. 1, p. 42-72, jan./abr., 2021 • 45 
da razão humana frente às atrocidades provocadas pelas duas guerras mundiais, que surgiu entre os anos de 1940 e 1950, na França, uma das maiores escolas do pensamento filosófico ocidental, o qual marcou muitas gerações de filósofos e que constitui o tema deste artigo, a saber: filosofia existencialista.

Conforme abordado resumidamente no parágrafo acima, desde os pré-socráticos houve um esforço para se compreender a essência do homem, isto é, para se identificar o princípio ou o fundamento da existência como se houvesse sempre uma base ou um epicentro a partir do qual todas as ações humanas pudessem ser racionalmente explicadas. Para os existencialistas, portanto, não há nenhum fundamento para a nossa existência, ou seja, não há nada nem ninguém que tenha escrito, previamente, o roteiro de nossas vidas, pois o homem, segundo o existencialismo, "[...] não é nada mais do que seu projeto. Ele não existe senão na medida em que se realiza e, portanto, não é outra coisa senão o conjunto de seus atos, nada mais além de sua vida" (SARTRE, 2014, p. 42).

Nessa perspectiva, um dos pensadores mais influentes do existencialismo e que constitui, por sua vez, a delimitação do tema deste artigo é o filósofo francês Jean-Paul Sartre que viveu entre os anos de 1905 e 1980, destacando-se como "[...] um dos mais importantes pensadores do século $X X$ e, sem sobra de dúvidas, a figura mais expressiva do existencialismo na Europa durante todo esse período" (PEREIRA, 2017, p. 12). Se na História do pensamento filosófico ocidental a busca pela definição do ser ocupou uma posição central no desenvolvimento da Filosofia, pode-se dizer que em Sartre $(1997 ; 2014)$ esse ser é o nada no sentido de que não há um princípio ou um 
arché que defina previamente o homem porque, para o filósofo francês, primeiramente o homem existe para depois tornar-se alguma coisa, ou seja, a existência precede a essência.

$\mathrm{Se}$ "[...] o homem primeiramente existe e, durante o processo de sua existência, ele se torna e vai construindo a sua essência" (PEREIRA; MELLO; BERVIQUE, 2011, p. 2) isso significa dizer que ninguém o concebeu previamente; que nenhuma pessoa ou entidade metafísica $o$ determinou com uma função específica a ser exercida no universo e que, portanto, não é dado, fechado, acabado e pronto, tais quais os objetos que, primeiramente, nascem na consciência do homem, para, depois, materializarem-se sob a forma, por exemplo, de uma tesoura, um copo, uma luva, uma mesa ou um carro que só podem ser aquilo para os quais eles foram concebidos e que Sartre irá tratálos, tecnicamente, como um Em-Si (SARTRE, 1997).

Assim, enquanto o Em-Si é aquilo que só poderia ser o que é; o Para-Si, outra nomenclatura técnica do arcabouço teórico e conceitual sartriano, é o homem, ou seja, é a consciência humana sempre incompleta e inacabada e que, por isso, está em constante transformação ou, como diz Sartre, apoiando-se em Edmundo Husserl, uma consciência transcendental que se desloca, permanentemente, para fora de si mesma.

Nesse sentido, se a consciência humana não é algo previamente determinado, então o ser humano está no mundo para criar, inventar, imaginar, propor, elaborar e reelaborar os seus próprios valores com toda a liberdade que as condições materiais, históricas e sociais os permitirem. A liberdade, na ótica sartriana, não é um atributo do homem; não é um objeto que se possua como um sabonete a ser utilizado no momento de se banhar. $\mathrm{O}$

Ágora Filosófica, Recife, v. 21, n. 1, p. 42-72, jan./abr., 2021 • 47 
homem não tem a liberdade, dizem os existencialistas, ele é a própria liberdade e, por isso, ele "[...] está condenado a ser livre" (SARTRE, 2014, p. 33).

Contudo, é preciso entender que a liberdade, para Sartre, não corresponde a noção de liberdade que circunda no senso comum, que a compreende, quase sempre, como ausência de barreiras ou limitações para a obtenção de algo. Contrariamente a essa perspectiva, a liberdade sartriana "[...] considera as resistências e as oposições que poderiam limitá-la" (SILVA; VACCARO, 2016, p. 103), ou seja, Sartre (1997; 2014) não nega as condições históricas, sociais, culturais, políticas, econômicas ou mesmo familiares, nas quais os sujeitos estejam inseridos e que podem representar, inclusive, limitações no sentido da obtenção de algo.

Assim sendo, a liberdade sartriana está sempre relacionada ao campo das escolhas e das possibilidades existenciais que possam representar a superação das condições iniciais nas quais os sujeitos estejam inseridos. Não é uma liberdade puramente idealizada ou sonhada, até porque Sartre $(1997 ; 2014)$ é um realista que se utiliza de conceitos como o ser-aí-no-mundo, de Martin Heidegger, para dizer que ser livre é atuar, livremente, aí no café de sua cidade, aí no escritório da empresa em que você trabalha ou aí na casa de campo em que você repousa com a sua família. É ser livre aí em um mundo concreto e objetivo, no qual se devam considerar as possibilidades históricas e sociais nas quais os sujeitos estejam inseridos.

Ser livre, para Sartre $(1997 ;$ 2014), não é desconsiderar as condições sociais e históricas nas quais os sujeitos estejam inseridos e, tão pouco, diz respeito à submissão total a essas condições. Ser livre, para o referido filósofo, é sempre se imaginar para além dessas 
condições iniciais e fazer todo um movimento de decisão e de ação para transformar a realidade, superando-a como em um movimento dialético. Não é por acaso que o pensamento sartriano revela o fato de que não é porque um prisioneiro não tenha conseguido fugir de sua prisão que ele se torna menos livre do que os demais homens, até porque, em última instância, ele sempre é livre para aceitar a sua condenação ou para se rebelar contra o carcereiro ou mesmo, em último caso, para abster-se de sua própria vida.

É certo que o leitor já tenha percebido o quanto Sartre levou a liberdade dos homens às suas últimas consequências, ao responsabilizá-los por tudo aquilo que eles fazem de si mesmos. Para o existencialismo, conforme revelam Silva e Vaccaro (2016, p. 103-104), o homem "[...] é o único responsável por suas ações, [pois não] há nada nem ninguém, nenhum imperativo categórico universalmente válido ou leis éticas gerais que possam determinar as suas escolhas ou indicar um caminho a seguir", visto ser o homem, "[...] antes de mais nada, o que ele tiver projetado ser" (SARTRE, 2014, p. 26).

Por conta de sua plena liberdade, dizem os existencialistas, o homem, muitas vezes, se sente angustiado e desamparado por não dispor de uma entidade metafísica com a qual possa compartilhar a responsabilidade de suas ações e decisões. Sente-se angustiado não apenas por ter que se responsabilizar por todas as suas atitudes, mas também por não encontrar um fundamento ou essência para si e para a vida ao perceber que tudo é contingência e gratuidade existencial, o que lhe causa náusea, título do primeiro romance de Sartre (2011) que o projetou ao panteão dos maiores escritores franceses do pós-guerra.

Ágora Filosófica, Recife, v. 21, n. 1, p. 42-72, jan./abr., 2021 • 49 
Apaixonado pela literatura desde criança, Sartre (1984) sempre sonhou em se tornar um grande escritor, pois via nos livros e na escrita seus campos de batalhas por meio dos quais ele lutava para dar sentido e significado a sua existência. Nas palavras do próprio Sartre (1984, p. 182), a sua pena era uma espécie de espada com a qual ele lutava para dar sentido à vida, ainda que ele reconheça a sua impotência, pois a vida não possui um sentido absoluto. Assim, o filósofo diz: "[...] não importa; faço e farei livros; são sempre necessários; sempre servem, apesar de tudo. A cultura não salva nada nem ninguém, ela não justifica. Mas é um produto do homem: ele se projeta e se reconhece nela".

Ainda que o referido filósofo reconheça que a escrita não confere um sentido absoluto à existência, ela é, na visão dele, uma forma do homem projetar-se no mundo. Nesse sentido, a escrita literária sartriana possibilitou que conceitos filosóficos, quase sempre densos, abstratos e de difíceis compreensões, especialmente para os "não iniciados", pudessem ser abordados de forma concreta e criativa, por meio das histórias de seus personagens, de modo que qualquer leigo em Filosofia seja capaz de pensar sobre as grandes questões existenciais.

Entretanto, nem sempre encontramos na literatura científica ou filosófica análises consistentes em relação às formas pelas quais o filósofo francês articulou a sua rede teórica e conceitual para materializar as histórias de seus personagens nos mais variados romances e peças teatrais que constituem o riquíssimo acervo de produções artísticas, literárias e filosóficas do pensador, sendo esta, portanto, a principal justificativa deste artigo. Dessa maneira, este trabalho está voltado para mostrar de que 
forma o filósofo francês fez uso do seu repertório teórico e conceitual para narrar a história de Antoine Roquentin que, ao longo do seu diário, vai tomando consciência da “[...] gratuidade da própria existência, a gratuidade dos seres e dos acontecimentos, a gratuidade de toda a existência, ou seja, a ausência de sentido, de significado" (DIAZ, 2017, p. 25). É essa consciência do absurdo, conforme Sartre (2011), que faz Roquentin sentir náusea, isto é, um mal-estar diante da constatação de que toda a realidade é pura contingência e gratuidade.

Desse modo, a questão de pesquisa que moveu o desenvolvimento deste artigo está esboçada da seguinte forma: De que maneira o filósofo Jean-Paul Sartre articulou os principais conceitos de sua filosofia, na obra $A$ Náusea, de modo a marcar as suas primeiras posições frente ao existencialismo francês?

$\mathrm{Na}$ tentativa de responder a esta questão de pesquisa, formulou-se 0 seguinte objetivo geral: compreender como o filósofo Jean-Paul Sartre articulou os principais conceitos de sua filosofia para construir a narrativa de sua primeira grande obra filosófico-literária, intitulada $A$ Náusea, marcando, assim, as suas primeiras posições frente ao existencialismo francês.

Para atingir ao objetivo geral, foram construídos três objetivos específicos que permitem, de certa forma, dar concretude à investigação e que estão esboçados da seguinte maneira: (1) Discutir a filosofia existencialista sob a ótica do filósofo francês Jean-Paul Sartre; (2) Identificar e caracterizar os principais conceitos articulados pelo filósofo para marcar as suas primeiras posições no existencialista francês e (3) Destacar trechos da obra filosófico-literária em análise, para evidenciar os principais conceitos da filosofia existencialista sartriana.

Ágora Filosófica, Recife, v. 21, n. 1, p. 42-72, jan./abr., 2021 • 51 
Para materializar esta pesquisa, pensou-se em uma estratégia metodológica pautada em uma investigação aplicada, uma vez que se busca entender a filosofia existencialista articulada ao universo da literatura. A pesquisa pode ser compreendida, também, como qualitativa por não envolver análises métricas e/ou quantitativas sobre o fenômeno em análise. Como ressalta Gil (2013), em sua classificação sobre os tipos de pesquisas científicas, este estudo, quanto aos seus objetivos, pode ser classificado como exploratório, avançando para descritivo, no qual o procedimento de pesquisa bibliográfico norteou todo o trabalho.

Ao dar prosseguimento à leitura do artigo, o leitor encontrará uma produção textual estruturada da seguinte forma: na primeira seção, consta esta introdução na qual se localizam os principais aspectos norteadores do artigo, tais quais: a questão de pesquisa, os objetivos e a metodologia, bem como a divisão temática das seções que o compõe. Na segunda seção, versa-se sobre a filosofia existencialista sob a ótica de Jean-Paul Sartre, na qual se discutem os principais conceitos do pensador. Já na terceira seção, o leitor se depara com um conjunto de trechos que foram retirados da obra $A$ Náusea para evidenciar a trama conceitual da filosofia sartriana que marca as suas primeiras posições no existencialismo francês e, por último, esboçam-se as principais considerações finais da pesquisa.

\section{A filosofia existencialista sob a ótica de Jean-Paul Sartre}

Diz-se, no ditado popular, que nenhuma fama ou prestígio é obtido sem batalhas ou dramas humanos e parece que esse dito também se aplica à filosofia sartriana

52 - Ágora Filosófica, Recife, v. 21, n. 1, p. 42-72, jan./abr., 2021 
e a sua forma de compreender o homem no mundo. $\mathrm{Na}$ verdade, na História do pensamento ocidental, nunca foi tão fácil se reconhecer, plenamente, a liberdade do homem. Como dito na introdução deste artigo, sempre houve um esforço intelectual, empreendido por séculos, para se identificar a arché, isto é, o elemento fundamental capaz de explicar tudo o que acontece com o homem em seus processos existenciais.

Nesse sentido, a filosofia existencialista empreendida por Sartre, Simone de Beauvoir, Albert Camus, Maurice Merleau-Ponty e tantos outros filósofos, somente para citar alguns, apesar de não ser unívoca, nunca quis colocar o homem na condição de desesperançado. Muito pelo contrário, a principal tese da filosofia existencialista é a de que o homem está condenado à liberdade e ele será, justamente, aquilo que ele definir ser e, por isso, Sartre (2014, p. 20) diz que o existencialismo é indispensável para “[...] tornar a vida humana possível ao declarar que toda verdade e toda ação implicam um meio e uma subjetividade humana".

Na verdade, a noção de subjetividade ocupa uma posição central para a constituição da filosofia existencialista. Contudo, o mundo ideal ou utópico, construído pela subjetividade ativa do indivíduo, não se configura como a única ou a mais importante noção da filosofia sartriana. Para além dessa noção, Sartre (2014) atribuiu à noção de ação um peso significativo que dá rosto humano ao existencialismo, diferenciando-o de tantas outras correntes filosóficas a exemplo do idealismo e do materialismo.

Para a corrente idealista a realidade objetiva e imediata, experimentada pelo homem, provém, diretamente, de seu pensamento e não de suas ações. 
Portanto, para os idealistas, "[...] todas as coisas são produtos das nossas idéias" (PERDIGÃO, 1995, p. 60), a qual não existe realidade humana desprendida de uma mente que a criou. Já o materialismo parte do pressuposto de que toda realidade material existe em si mesma e independe da mente que a concebeu. Aliás, para os materialistas, é a partir da realidade objetiva e imediata que a mente de um sujeito é constituída.

Dessa maneira, Sartre (1997) reconheceu tanto o papel da objetividade quanto o da subjetividade na constituição do ser. Para ele, não há porque desconsiderar a materialidade do mundo, isto é, das coisas como elas realmente o são em si mesma e que, tecnicamente, o filósofo chamou de Em-Si. Entretanto, apesar de reconhecer a realidade objetiva, Sartre (1997) diz que ela, em si mesma, nada significa e para que essa realidade possa ganhar tom, cheiro, cor e, portanto, significado haverá, sempre, de existir uma consciência que interprete e atribua sentidos e valores aos objetos do mundo.

Nesse sentido, Sartre (2014, p. 47) nos diz que o homem não seria resultado, unicamente, de uma determinação da realidade objetiva e imediata como pensavam os marxistas que tratavam "[...] todos os homens, inclusive a si mesmos, como objetos, isto é, como um conjunto de reações determinadas que em nada se distingue do conjunto de qualidades e fenômenos que constituem uma mesa, uma cadeira ou uma pedra". Contrariamente, diz Sartre $(1997 ;$ 2014), o homem é aquele que constrói a sua História e para construí-la ele sempre parte da negação da realidade objetiva e imediata, constatada pelos sentidos, para ir à procura de um mundo ideal e perfeito, forjado pela sua imaginação, para, só depois desse mundo imaginado, retornar à realidade para 
criticá-la e superá-la. A esse movimento da consciência ativa, Sartre (1997) chamou de circuito da ipseidade que é esse "[...] movimento temporal de ida e volta; do presente ao futuro e vice-versa" (PERDIGÃO, 1995, p. 78) que nos permitem atribuir significado ao mundo e a tudo aquilo que nos constituem.

Para Sartre (1997; 2014), não há razões para se buscar fundamentos, essências ou valores morais eternos e divinatórios que determinariam as ações e condutas dos homens como se eles não fossem consciências ativas e pensantes. Na condição de existentes, os homens são os únicos seres da natureza capazes de se autodeterminarem e assumirem todas as responsabilidades pelas suas escolhas. Isso implica na visão de Sartre (2014, p. 44), que não é possível a um covarde deixar de assumir a sua covardia, até porque ele não possui "[...] um coração, um pulmão ou um cérebro covarde, mas ele se modelou um covarde por meio de seus atos".

Sartre (2014) lembra, entretanto, que muitas pessoas possuem o horror de se sentirem responsáveis pelas suas escolhas, uma vez que "[...] o que as pessoas gostariam mesmo é que nascêssemos covardes ou heróis" (p. 44). Nesse sentido, conforme revelou Allouche (2019, p. 79), a filosofia sartriana chega a ser desconfortante, porque ela "[...] aponta com o dedo a miséria de vidas abandonadas pela frouxidão" que nunca se sentiram responsáveis por aquilo que elas mesmas fizeram de suas vidas.

É certo que a lucidez atribuída ao homem pela filosofia existencialista sartriana, tenha servido para incomodar muitas pessoas que o criticavam pelas ruas e avenidas de Paris, nas décadas de 1940, 1950 e 1960, sem,

Ágora Filosófica, Recife, v. 21, n. 1, p. 42-72, jan./abr., $2021 \cdot 55$ 
muitas vezes, conhecerem, de fato, a sua proposta filosófica. O existencialismo foi objeto de várias acusações advindas de cristãos e marxistas. Entre os cristãos, a filosofia sartriana foi acusada de incentivar o quietismo, a desilusão e a solidão entre os homens, uma vez que não existindo Deus ou quaisquer outras entidades metafísicas que regessem a vida terrena, não haveria mais esperanças de bons dias para a humanidade. Outra crítica católica, direcionada a Sartre (2014), é a de que a sua filosofia teria deixado o homem descrente de suas potencialidades ao fazê-los desacreditar das coisas belas e alegres do mundo, abandonando o lado luminoso da vida.

Além dos católicos, Sartre (2014) também enfrentou duras críticas tecidas pelos marxistas, os quais afirmavam que a ênfase dada pelo filósofo aos aspectos subjetivos da condição humana tornava os homens mais individualizados e descontextualizados das questões reais do mundo objetivo. Para os marxistas, a filosofia existencialista enfraqueceria a solidariedade entre os homens, uma vez que passariam a não mais enxergarem outros homens que se encontravam fora do mundo idealista e contemplativo proposto pela filosofia sartriana.

Foi nesse contexto, que Sartre aceitou o desafio de realizar uma conferência sobre o existencialismo, na qual ele buscou rebater a cada uma das críticas que vinha recebendo e que o acusava de enfatizar, em seu pensamento, apenas os aspectos ruins da vida. Nas palavras de Elkaim-Sartre (2014, p. 12), essa conferência permitiu a Sartre "[...] apresentar ao público uma exposição coerente e mais justa de sua filosofia", cujos pressupostos se sustentaram em uma única e válida premissa: a liberdade humana. 
A liberdade implica desfazer um equívoco, segundo o qual a liberdade significaria ter condições de obter o que se quer, ou melhor, significaria uma ausência de impedimentos externos para se alcançar o que se quer. 0 verdadeiro conceito de liberdade, diz Sartre, não é esse; não se trata de obter o que se quer, mas de querer, autonomamente, determinar-se a querer por si mesmo. Querer aqui, evidentemente, não é só no sentido de voluntário, reflexivo, mas no sentido de largo, que envolve toda a ação humana (MOUTINHO, 1995, p. 73).

De modo geral, quando se pensa em liberdade, no senso comum, imagina-se uma situação na qual não existam limites ou impedimentos para as ações humanas. Quase sempre esse conceito está relacionado à movimentação livre dos indivíduos, visto não ser incomum se ouvir expressões do tipo: eu gostaria de pegar o meu carro e sair, livremente por aí, sem nenhum tipo de barreira, determinação ou restrição. Mas, o conceito de liberdade, apontado acima, não se restringe a ideia de circulação livre e plena dos sujeitos ou mesmo de obtenção de algo sem quaisquer tipos de restrições. De maneira oposta, o sujeito só possui liberdade porque ele não pode realizar tudo aquilo que deseja e, por isso, precisa fazer escolhas diante das possibilidades que a vida, naturalmente, Ihe traz.

Assim, quando se fala em liberdade, ressalta-se a autonomia de escolha dos sujeitos, ou seja, deseja-se enfatizar as suas capacidades de eleições diante de determinadas circunstâncias históricas, sociais, políticas, econômicas, éticas e morais, nas quais eles estarão 
imersos e com as quais terão que tomar as suas decisões e isso não implica pensar que os sujeitos possam “[...] fazer o que se quer, mas o que se pode" (PERDIGÃO, 1995, p. 89).

Sartre (1997) definiu os sujeitos, ontologicamente, como seres que não são o que são, e o que realmente são é o que ainda não são. Mas o que significa esse trocadilho filosófico? Para ele, o Para-Si representa, conforme já dito, a consciência que não se define, previamente, pelo seu passado, ainda que este esteja presente nos sujeitos. Nesse sentido, Sartre (1997) vai dizer que tudo o que antecedeu o homem não o determina, pois o passado de um homem já não é o homem. O passado, enquanto um Em-Si, não possui capacidade alguma de determinar o que o homem é, porque, em última instância, o homem é sempre uma incompletude que o coloca na condição de um projeto existencial sempre por se fazer não havendo, portanto, quaisquer determinações passadas.

Dessa forma, é o futuro que definem os sujeitos enquanto projetos existenciais inacabados. $\mathrm{E}$ como o futuro é sempre aquilo que está por vir, isto é, aquilo que está em aberto e indefinido, os homens são, efetivamente, o que ainda não são. Por conseguinte, são a transcendência; são projetos existenciais em curso ou possibilidades de ser. Dessa maneira, o leitor já percebeu que, como o mundo, originalmente, não tem um sentido a priori, ou seja, não há nenhum valor universal a ser seguido, tudo o que acontece em suas vidas está na ordem da pura gratuidade existencial.

Desse modo, se o futuro está sempre em aberto e “[...] nenhum sentido pode ser dado à vida a partir de referenciais morais predefinidas" (ALLOUCHE, 2019, p. 105), então o homem será exatamente aquilo que 
escolher para si, porque ser livre, para o existencialismo, implica reconhecer o ser humano sempre como consciência "[...] de ser o autor de um evento ou um objeto. Trata-se da consciência de que a situação só existe pela liberdade; ela não é separada e anterior a mim. Ela só existe por mim, exatamente na medida em que minha liberdade a colore, fazendo-a aparecer desta ou daquela maneira" (MOUTINHO, 1995, p. 77).

Logo, todas as escolhas realizadas livremente pelo homem implicam o reconhecimento consciente de sua liberdade. É essa consciência de ser livre sem quaisquer determinações anteriores a sua existência que se chama, no existencialismo, de consciência de responsabilidade que coloca o homem "[...] em posse daquilo que ele é [fazendo] repousar sobre ele a responsabilidade total por sua existência" (SARTRE, 2014, p. 26).

Apesar de Sartre ter sido acusado de pregar uma filosofia que tornava o homem individualista, sonhador, desesperançado e inativo, ele nunca defendeu uma liberdade que não fosse de ação e que estivesse descompromissada com a coletividade. Para o existencialismo sartriano, todas as vezes que um homem escolhe a si mesmo, ele está, automaticamente, escolhendo o modelo de homem que ele quer para o mundo. Perdigão (1995, p. 115) ratifica esse olhar sartriano ao ressaltar que ao escolher-se, o homem o faz “[...] por toda a humanidade, como se fosse 0 representante de todos. Escolhendo o homem que eu quero ser, escolho o modo como todos os homens deveriam ser". Isso implica dizer que, se eu escolho me casar, ter filhos e viver para a minha família, por exemplo, eu estou, automaticamente, escolhendo, também, um modelo de homem para expor ao mundo.

Ágora Filosófica, Recife, v. 21, n. 1, p. 42-72, jan./abr., $2021 \cdot 59$ 
Ser livre e possuir a consciência dessa liberdade faz o homem se encontrar consigo mesmo, provocando-lhe angústia, desamparo e desespero por saber que, lançado ao mundo sem nada e sem ninguém que o fundamente, preliminarmente, ele é responsável, diretamente, por atribuir sentido à sua vida. Nesse sentido, a angústia surge não somente porque $\mathrm{o}$ homem encontra-se consigo mesmo, mas também porque ao se escolher, individualmente, ele escolhe, ao mesmo tempo, toda a humanidade, uma vez que a angústia vem, justamente, da consciência de que "[...] sou obrigado, a cada instante, a realizar ações exemplares. Tudo acontece para cada homem como se a humanidade inteira estivesse sempre com os olhos sobre o que ele faz para agir de maneira semelhante" (SARTRE, 2014, p. 30).

E haveria como se desviar da angústia? O pensamento sartriano diz que é impossível porque os homens são seres angustiados por natureza. Para o filósofo francês, "[...] é na angústia que o homem toma consciência de sua liberdade. A angústia é o modo de ser da liberdade como consciência de ser; é na angústia que a liberdade está em seu ser, colocando-se a si mesma em questão" (SARTRE, 1997, p. 72). Todavia, apesar dos homens serem criaturas da angústia, buscam formas de dissimular esse sentimento e, uma delas é quando agem de má-fé.

No senso comum, quando se ouve a expressão máfé, quase sempre remete-se a uma situação na qual um indivíduo ou um conjunto de pessoas "quebrou" ou "traiu" a confiança que Ihes foi atribuída. Assim, alguém que agiu de má-fé, no ditado popular ou mesmo no campo jurídico, é alguém que agiu com falta de ética e que não respeitou os valores morais vigentes em uma dada sociedade. No 
campo da gestão pública brasileira, um servidor público que tenha recebido, no exercício de suas funções, valores em dinheiro ou gratificações incompatíveis com o exercício de sua função público, age de má-fé e, portanto, deve responder, legalmente, pelos seus atos de desrespeito aos valores morais que sustentam a dinâmica de funcionamento do serviço público.

Mas a má-fé, no campo da filosofia sartriana, parece ser mais simples, quando comparado ao arcabouço jurídico e legal sobre o tema, e, ao mesmo tempo, mais complexa, pois está relacionada, diretamente, a um movimento do homem para negar aquilo que ele é: a liberdade. Desse modo, quando se fala de má-fé, na perspectiva existencialista, refere-se a todo tipo de tentativa humana de negar a sua própria consciência que é a liberdade e, por isso, a responsabilidade dos seus atos praticados.

Ontologicamente condenados à liberdade, não resta ao homem recorrer a quaisquer fatores externos a ele mesmo como fonte de justificação ou de explicação para os seus atos e, quando isso acontece, está-se diante de uma situação de má-fé sartriana. Não é incomum, por exemplo, se encontrar pessoas que afirmam que não se casaram ainda porque não conseguiram achar um bom ou uma boa companheira ou que não escreveram um livro porque não possui tempo disponível para fazê-lo ou ainda que estão no emprego ruim porque possuem contas para pagar. São pessoas, diria Sartre (1997; 2014), que estão sempre em busca de um culpado, que não sejam elas, para as suas próprias ações.

Por isso, todas as vezes que se age de má-fé "[...] é a nossa própria consciência que estamos tentando enganar e não a do outro" (ALLOUCHE, 2019, p. 61). Assim, todas as 
vezes que eu tento encontrar fundamentos prévios para os valores humanos com os quais eu me deparo, eu estou agindo de má fé. Os existencialistas diriam, também, que todas as vezes que o homem cria um personagem de si mesmo para rotinizar o seu olhar e suas ações diante da gratuidade existencial, estar-se agindo de má-fé. Ou seja, toda as vezes em que o homem tenta assumir um papel social previamente criado por ele ou pela sociedade, conforme análise do garçom de café empreendida por Sartre (1997), em o Ser e o Nada, que retira do sujeito aquilo que ele tem de mais autêntico, estar-se, em última instância, agindo-se de má-fé. E como agiu Antoine Roquentin ao se deparar com um mundo totalmente sem sentido e significados prévios, que lhe permitiu encontrarse não com o Marques de Rollebon, mas consigo mesmo?

\section{O drama da liberdade: o encontro de Antoine Roquetin consigo mesmo}

Se Jean-Paul Sartre foi, em algum momento da História, um dos maiores intelectuais franceses de sua geração, é certo que essa posição somente foi ocupada após a publicação de uma de suas maiores obras filosófico-literária intitulada $A$ Náusea que, sem sombra de dúvidas, o projetou ao panteão dos grandes escritores franceses de sua geração ao tratar temas filosóficos e outros dilemas humanos literariamente.

Nas memórias da Simone de Beauvoir (2009), sua companheira intelectual e amorosa de muitos anos, há registros de que $A$ Náusea foi escrito em sucessivas versões, até mesmo porque o jovem Sartre apesar de apaixonado pela literatura, não conseguiu, nas primeiras versões do livro, expor os temas filosóficos de uma forma mais inventiva, criativa e imaginativa, o que tornou os 
primeiros escritos da obra demasiadamente densos, quase um tratado filosófico no sentido mais estrito do termo.

Conta Simone de Beauvoir (2009) que Sartre trabalhou, em média, de quatro a seis anos para produzir a versão final da ficção até entregá-la ao editor da Gallimard para a avaliação do manuscrito. Nesta empreitada, ele contou, inclusive, com a ajuda do seu amigo Paul Nizan que, na época, trabalhava na referida editora. Sabe-se que o editor leu a obra e gostou muito do livro, fazendo-lhe uma única exigência: de que trocasse o título original da obra que era Melancolia para A Náusea, já que era uma situação freqüente na narrativa e que revelava o estado de espírito do personagem principal.

Nesse sentido, a obra foi um sucesso não só de vendas mas também, muito provavelmente, de críticas, possuindo uma série de resenhas importantes que são amplamente encontradas na literatura. Entre essas inúmeras resenhas, pode-se destacar aquela elaborada pelo filósofo franco-argelino, Albert Camus, que, no mesmo ano de publicação da obra, em 1938, fez uma resenha elogiosa da ficção sartriana. Escrita sob a forma de diário para não deixar "[...] escapar as nuanças, os pequenos fatos, ainda quando pareçam insignificantes e, sobretudo, classificá-los" (SARTRE, 2011, p. 13), A Náusea registra o dia a dia de um historiador que decidiu escrever a biografia de um famoso diplomata francês do século XVIII chamado Marques de Rollebon.

A ficção sartriana é composta por uma série de personagens que, de acordo com o professor Franklin Leopoldo e Silva (2015), são tipos simbólicos com os quais Sartre (2011) pretendia dialogar para refletir sobre a condição humana. O principal personagem da ficção é

Ágora Filosófica, Recife, v. 21, n. 1, p. 42-72, jan./abr., 2021 • 63 
Antoine Roquentin, um historiador viajado que já havia passado pela Europa Central, África do Norte e Extremo Oriente. Roquentin era um homem de, aproximadamente, trinta e cinco anos de idade, solitário e que se julgava sem grandes problemas financeiros, mas que, ao mesmo tempo, pode ser compreendido como "[...] um rapaz sem importância coletiva", ou seja, "apenas um indivíduo" (SARTRE, 2011, p. 9).

Para além de Antoine Roquentin, a ficção possui outros personagens, a exemplo do Autoditada, Anny, a Senhora Françoise, dona do Rendez-vous des Cheminots e a moça que trabalhava para ela, a qual estava sempre à disposição de Roquentin para atendê-lo, especialmente nos momentos em que ele tentava fugir, desesperadamente, da contingência, a senhora Madeleine. O Autodidata é um tipo de indivíduo, de acordo com Sartre (2011), que se pensava enquanto um verdadeiro humanista clássico. Esse personagem é um ser que lê os livros da biblioteca sempre da esquerda para a direita, seguindo a ordem alfabética de seus autores porque ele acreditava que para entender o mundo ou estar apto a interpretá-lo era necessário esgotar todo o conhecimento produzido pela humanidade.

Outra personagem importante da ficção, que é muito citada por Roquentin durante a sua estadia em Bouville, é Anny, uma moça com a qual ele teve um caso amoroso e com a qual ele desejava se reencontrar novamente, sempre com a esperança de que pudesse reatar o relacionamento. Anny, conforme relata Sartre (2011, p. 88), buscava realizar o "momento perfeito". A personagem fazia todo esforço para combinar, em um só instante, pessoas, gestos, roupas, oratória, sons, imagens e etc, de modo que ela pudesse criar o "momento" ou 
"instante perfeito" de sua existência e "[...] se o instante não se prestava para isso, se desinteressava de tudo, a vida desaparecia de seus olhos, ela se arrastava preguiçosamente como uma meninona na idade ingrata".

O interessante é que tanto Roquentin quanto Anny e o Autodidata são personagens utilizadas por Sartre para mostrar tipos humanos que negam a vida e que, portanto, evitam a contingência e a liberdade, pois querem viver pensando que a vida, em si mesma, possui um significado, um fundamento, uma razão, uma causa ou uma organização lógica e racional, a priori, a partir da qual se possa explicar a existência. E foi com essa necessidade de revelar a vida do Marques de Rollebon que Antoine Roquentin decidiu escrever a biografia do diplomata, indo morar, por três anos, na cidade de Bouville porque "[...] Rollebon era castelão de Marommes. Antes da guerra, ainda havia nesse burgo um descendente seu, um arquiteto chamado Rollebon-Campouyré e que, quando morreu, em 1912, deixou um importante legado para a biblioteca de Bouville: cartas do marquês, um fragmento de diário, papéis de toda espécie" (SARTRE, 2011, p. 26).

Dessa maneira, Roquentin passou a conviver com os moradores de Bouville. Percorria as ruas, praças, estações de trens, cinemas, teatros, museus, bares e restaurantes além, é claro, da própria biblioteca que se tornou o seu local de trabalho. Nessa empreitada solipsista, Roquentin registrava cada um dos rostos e gestos dos habitantes de Bouville. Observava as roupas, os hábitos, os costumes e os objetos utilizados pelas crianças e adultos e, sobretudo, o comportamento da pequena burguesia da cidade. O mais interessante é que a rotina de vida dos moradores de Bouville, que não assinalava qualquer ineditismo ou originalidade, tranquilizava-o, uma vez que passava a ideia

Ágora Filosófica, Recife, v. 21, n. 1, p. 42-72, jan./abr., $2021 \cdot 65$ 
de que tudo estava no seu devido lugar, pois havia uma ordenação lógica e racional que Ihe permitia explicar todos os acontecimentos.

Apesar disso, a tranqüilidade de Antoine Roquentin foi, aos poucos, tornando-se ameaçada. A sua convivência solipsista com a cidade e com os moradores de Bouville foi Ihe deixando cada vez mais preocupado, já que ele começou a ter uma hiper lucidez em relação à ausência total de sentido para a sua existência. As palavras de Roquentin são reveladoras a respeito de suas primeiras percepções sobre a falta de sentido da vida. "[...] Pela primeira vez me incomoda estar só. Gostaria de falar com alguém sobre o que está me acontecendo, antes que seja tarde demais, antes que eu comece a assustar os garotinhos" (SARTRE, 2011, p. 22).

Mas o encontro com a liberdade foi dramático para Antoine Roquentin. Ele que, até então, pensava ser capaz de dar uma ordenação lógica e racional para a vida, arvorando-se, inclusive, em justificar a existência de outro homem, o Marques de Rollebon, por meio de registros históricos, de repente se vê diante da impossibilidade de explicar, racionalmente e ordenadamente, a sua própria existência ainda que sempre desejasse "[...] momentos de vida que tivessem uma sequência e uma ordem como os de uma vida que recordamos" (SARTRE, 2011, p. 61).

O drama da liberdade foi, aos poucos, se acentuando na vida de Antoine Roquentin, uma vez que ele começou a perceber que a vida não tinha nenhum sentido a ser buscado; nenhum fundamento a ser procurado ou nenhuma razão que pudesse explicá-la. O professor Franklin Leopoldo e Silva (2015) vai dizer que isso irritava profundamente Antoine Roquentin porque ele gostaria que houvesse uma ordenação na vida dos indivíduos, tal qual 
aquela que ocorre com os personagens de um romance policial. Nesse estilo literário, diz o professor, nenhum fato ou acontecimento escapa ao controle rígido do autor da ficção e a vida, lamenta Roquentin, não é como um romance policial, no qual exista um autor que ordene todos os acontecimentos da vida. Em face da constatação da ausência de um autor que estabeleça um papel fixo para o homem, Roquentin admite que a vida é contingência, acaso e puro absurdo, ou seja, as coisas aparecem sem que se consiga, necessariamente, explicálas.

$O$ essencial é a contingência. $O$ que quero dizer é que, por definição, a existência não é a necessidade. Existir é simplesmente estar aqui; os entes aparecem, deixam que os encontremos, mas nunca podemos deduzilos. Creio que há pessoas que compreenderam isso. Só que tentaram superar essa contingência inventando um ser necessário e causa de si próprio (SARTRE, 2011, p. 175).

Um dos aspetos interessantes que chama à atenção na fala de Roquentin é que existir é simplesmente estar-aíno-mundo com os outros entes sem nenhum tipo de papel social previamente definido ou determinado. Dessa maneira, como não há nenhum autor que tenha escrito a vida humana antes mesmo dos sujeitos vivê-la, estes são totalmente livres para, dentro de condições históricas e sociais previamente existentes, escolher o seu destino, assumindo as responsabilidades por suas ações. Porém, ser livre é perceber que o seu destino depende sempre das suas próprias escolhas, o que torna a existência dramática porque, na condição de livre, não há razões 
para se imputar responsabilidades a outras pessoas.

A dramática fuga da liberdade é muito bem trabalhada na obra sartriana, visto que, em diversos momentos da ficção, há evidências da má-fé de Antoine Roquentin que tenta se refugiar da contingência ao querer encontrar um autor, um sentido, uma razão ou uma rotina que the passasse a sensação de acabamento e de completude da vida e, com isso, the retirasse a responsabilidade de suas ações em um mundo ainda por se construir. Diante de suas sucessivas crises de hiper lucidez em face da contingência existencial, Roquentin queria encontrar uma rotina na qual ele pudesse ter a certeza de que não havia nada a temer. No Rendez-vous, por exemplo, ele se apegava à rotina do senhor de Rouen que era um rapaz "[...] baixinho e muito asseado, com bigodes pretos encerados e uma peruca" que se hospedava, semanalmente, no local e cujo barulho da chegada desse senhor na hospedaria já acalmava o coração de Roquentin porque ele via regularidade nesta ação e, assim, professava que não havia quaisquer motivos para se "[...] temer um mundo tão regular" (SARTRE, 2011, p. 15).

Outra situação reveladora da má-fé de Antoine Roquentin diante da ausência de explicação para a gratuidade existencial era o hábito que ele tinha de, diante da sensação de estranhamento da realidade, pedir à funcionária do Rendez-vous, senhora Madeleine, para colocar uma música no gramofone intitulada Some of these days. Ao ouvir essa canção de jazz, Roquentin se sentia feliz porque constatava a sensação de acabamento de uma letra musical que possuía início, meio e fim e cuja arte sobreviveria à contingência da vida. Por conseguinte, todas as vezes que ele ia ao Rendez-vous e ouvia a citada 
canção, dizia ele, eu começava "[...] a me reanimar, a me sentir feliz. Ainda não é nada de extraordinário, é uma pequena felicidade de Náusea: ela se espalha no fundo da poça viçosa, no fundo de nosso tempo. Mal nasceu e já parece velha, tenho a impressão de conhecê-la há vinte anos" (SARTRE, 2011, p. 38).

No decorrer de sua estadia, em Bouville, Antoine Roquentin foi se esvaindo de sua postura de má-fé ao desmontar, pouco a pouco, o personagem de si mesmo que ele havia estabelecido inicialmente para fugir de sua própria liberdade e, conseqüentemente, das implicações que ela traz: responsabilidade, angústia, desespero e desamparo. Ao perceber que não havia nenhum sentido a ser buscado na vida e que a construção da realidade se daria pelo movimento ativo de sua consciência, Roquentin afirmou que a sensação de náusea, advinda da percepção da ausência total de sentido prévio da existência humana nunca o largaria, pois “[...] A náusea não me abandonou e não creio que me abandone tão cedo; mas já não estou submetido a ela, já não se trata de uma doença, nem de um acesso passageiro: a náusea sou eu" (SARTRE, 2011, p. 169).

Não sendo mais possível negar a náusea, Antoine Roquentin decidiu, conforme relata o professor Franklin Leopoldo e Silva (2015), superar essa situação e, para isso, ele desistiu de escrever a biografia do Marques de Rollebon, que seria uma espécie de subordinação ao real e, portanto, à História e aos fatos concretos da realidade para escrever uma obra ficcional, criativa, imaginativa e inventiva. Então, não seria um livro sobre um homem em específico até porque, nessa fase de sua vida, ele já tinha percebido que nenhum homem é capaz de justificar a existência de outro. Assim, Roquentin optou por escrever 
uma história de aventura, isto é, uma ficção "[...] que fosse bela e dura como aço e que fizesse com que as pessoas se envergonhassem de sua existência" (SARTRE, 2011, p. 234), nascendo, por sua vez, a obra literária que acabou de ser analisada brevemente neste artigo.

\section{Considerações finais}

Este artigo procurou compreender a forma pela qual o filósofo Jean-Paul Sartre articulou os principais conceitos de sua filosofia para construir a narrativa do seu primeiro romance filosófico-literário, o qual o levou ao panteão dos grandes escritores franceses de sua geração e marcou as suas primeiras posições frente ao existencialismo francês.

É certo que a ficção literária analisada neste artigo não pode ser entendida como a filosofia última de Sartre, até porque o pensamento do filósofo, quando da escrita da obra, que ocorreu antes da segunda Guerra Mundial, era muito diferente da sua filosofia do pós-guerra, quando - peso da História recaiu sobre as cabeças da humanidade. Nessa transição, Sartre percebeu que sozinho o homem não transformava a História e que a força das transformações sociais advinha do engajamento, conceito que foi tratado em diversos ensaios críticos e filosóficos, bem como nos romances e peças teatrais do referido pensador.

Apesar de não ser a filosofia por excelência de Sartre, A Náusea pode ser entendida como uma espécie de espelho, que projeta sobre cada leitor a imagem de si mesmo para que esse se veja enquanto ser cada vez menos determinado, acabado, pronto e concluído e passe a se ver cada vez mais, como sujeito inacabado, incompleto, imperfeito e, portanto, totalmente livre para 
construir a sua vida com a maior autenticidade possível.

\section{Referências}

ALLOUCHE, F. Ser livre com Sartre. Tradução de João Batista Kreuch. Petrópolis: Vozes, 2019.

ARANHA, M. L de A; MARTINS, M. H. P. Filosofando: introdução à filosofia. São Paulo: Moderna, 2000.

BEAUVOIR, S. Memórias de uma moça bemcomportada. Tradução de Sérgio Milliet. Rio de Janeiro: Nova Fronteira, 2009.

CHAUÍ, M. Convite à filosofia. 12. ed. São Paulo: Ática, 2002.

DIAZ, L. A. M. Roquentin, contingência e náusea. Eleuthería, Campo Grande, v.2, n.2, p.24-45, jun./nov. 2017.

ELKAIM-SARTRE, A. Situação da conferência. IN: SARTRE, J. P. O existencialismo é um humanismo. 4.ed. Petrópolis: Vozes, 2014

GIL, A. C. Como elaborar projetos de pesquisa. 5.ed. São Paulo: Atlas, 2013.

MOUTINHO, L. D. S. Sartre: existencialismo e liberdade. São Paulo: moderna, 1995.

PERDIGÃO, P. Existencialismo e liberdade: uma introdução à filosofia de Sartre. Porto Alegre: L\&PM, 1995. PEREIRA, E. F.; MELLO, T. V.; BERVIQUE, J. A. O homem e a angústia existencial em Jean-Paul Sartre. Revistas Científicas Eletrônicas, São Paulo, ano 9, n. 16, p.1-8, maio 2011.

PEREIRA, P. S. da M. A literatura como projeto filosófico: análise do romance A Náusea, de Jean-Paul Sartre. Revista Mosaicum, Teixeira de Freitas - BA, v.13, n.26, p.11-29, jul./dez.2017.

REALE, M. Introdução à filosofia. São Paulo: Saraiva, 
1989.

SARTRE, J. P. As palavras. Tradução de J. Guinsburg. 6. ed. Rio de Janeiro: Nova Fronteira, 1984.

SARTRE, J. P. O ser e o nada: ensaio de fenomenologia ontológica. Tradução de Paulo Perdigão. 5.ed. Rio de Janeiro: Vozes, 1997.

SARTRE, J. P. A náusea. Rio de Janeiro: Nova Fronteira, 2011.

SARTRE, J. P. O existencialismo é um humanismo. 4.ed. Petrópolis: Vozes, 2014.

SILVA, F. L. Literatura fundamental 72: A Náusea. 2015. Disponível em:

https://www.youtube.com/watch?v=Wvt 2qeiP2g>. Acesso em: 03 mar. 2020.

SILVA, L. C. da; VACCARO, M. M. A constituição do sujeito: uma reflexão a partir de Jean-Paul Sartre. Revista de Psicologia, Fortaleza, v.7, n.2, p.99-109, jul./dez.2016.

Anderson Luis da Paixão Café

É doutor em Difusão do Conhecimento e Mestre em Ciência da Informação pela Universidade Federal da Bahia (UFBA). Cursou a sua especialização em Metodologia do Ensino, Pesquisa e Extensão pela Universidade do Estado da Bahia (UNEB), após ter concluído o seu Bacharelado em Biblioteconomia e Documentação também pela Universidade Federal da Bahia. Atualmente, está cursando o seu último semestre da licenciatura em Filosofia ofertada pelo Centro Universitário Internacional (UNINTER) e, profissionalmente, encontrase vinculado ao quadro de servidores permanentes do Tribunal de Justiça do Estado da Bahia (TJBA).

E-mail: andersoncafe2011@gmail.com

Submetido: 01/02/2021

Aprovado: 01/04/2021 